\title{
バレーボール選手に見を手舟状骨疲労性骨折
}

$\begin{array}{ccccc}\text { 九州厚生年金病院整形外科 䓢 } & \text { 田 } & \text { 日 出 } & \text { 等 } \\ & \text { 石 } & \text { 西 } & & \text { 猛 } \\ & \text { 元 } & \text { 村 } & \text { 資 } & \text { 治. }\end{array}$

\section{Stress Fracture of the Carpal Scaphoid in the Volley Ball Player \\ By}

\section{Hideto Sonoda, Takeshi Ishinishi, Sukeharu Motomura}

Kyushu Welfare Pension Hospital

オリンピックを 2 年後に控えて，スポーツに対する 関心あたかまりつつあるが, スポーツは, 体位向上と 趣味として，楽しんでいられる反面，一方では幐つ為 に，長い間，きびしい絶えまない練習と，努力を必要 とするむので，とれが為にや〉すすると，自己の能力 の限界を越えて，過激な運動を強制される結果とな る. 従つてスポーツによる障害す，多くみられるのは 当然と云えよう。

最近相次いで, 同一高校のバレーボール選手で, 両 手関節の運動痛を主訴として 来院したすのが二名あ り，そのいずれにもレ線上，両手舟状骨々折の像をみ とめた．乙の骨折が疲労性骨折であると考えられたの で，同高校バレーボール部員 15 名の検診を行つた結 果, 更にその初期と思われる1名を発見した。とれら の三症例を報告すると共に，との様な骨折の発生機転 につき検討を加えてみたい.

症例:116才 男子 高校バレー選手 中衛 既往歴 特記すべき事項なし.

家族歴 特記すべき事項なし.

現病歴昭和 35 年 4 月, 高校入学と同時に, バレー 部に籍を置き, 每日平均 3 時間以上の練習を行つてい た処，バレーを始めて 7 ケ月后から，雨手関節部に倦 怠感を覚える様になつたが，別に運動痛はなかつたの で，そのま〉練習を続けていた．翌年の 1 月下旬頃よ り，スパイクボールをレシーブするたびに，右手関節 背側に疼痛を覚え, 次で 3 月中旬頃には, 反対の左手 関節に全く同様な運動痛を来す様になつた，それでむ 尚毎日激しい練習を続けていた為か，上記の運動痛は 少しあ軽快せず，4月中旬になつて両手関節部の運動
痛と腫脤を主訴として私達の外来を受診した。

\section{現 症}

両手関䬣背側に軽度の腫脹が見られるが, 発赤, 熱 感は認められず，雨手舟状骨に相当する部位に圧痛を 証明し, 左手より右手の方に压痛が著明であつた. 手 関節の可動性は背掌屈共に殆んど制 限されていない が, 背屈時には手船状骨部に運動痛を訴えている. 又 抵指の過度外転により, 手関節栓側に疼痛があるが, 拇指及び示指からの介達圧痛は極〈軽度に認められ た。尚知覚障害及び手指の運動障害はない。

\section{レントゲン所見}

初竞時の両側手舟状骨の前後像で, その略中央部で 骨長軸を横浙する明膫な透明带がみられ，完全に二分 されている（写真 1 )。

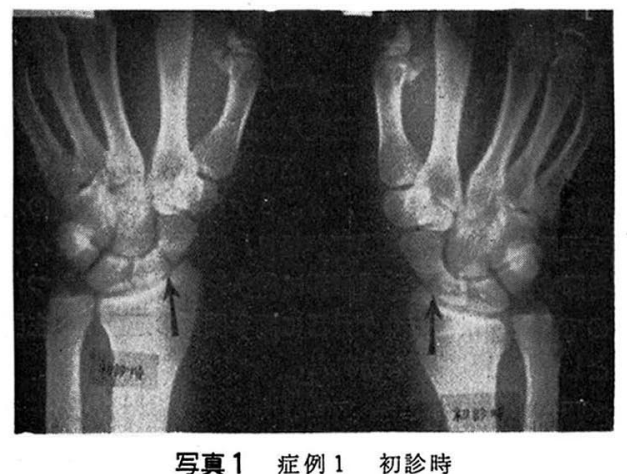

治療

最初症状の強い右手舟状骨に観血的に銀行骨による 骨釬移植術を，その后 2 ケ月して左手舟状骨に骨移植 
を行い, 夫々術后前腕から掌指関節迄ギプス包帯で固 定した.

\section{手術所見}

クーレンカンプ氏麻酔の下に, 右橈骨荃状突起から 末梢に向い, 長拇指外転筋腱, 長拇指伸筋腱の間, 即 ち「たばてつぽ」の中心に約 $2.5 \mathrm{~cm}$ の皮原切開を加え て, 手舟状骨に達した. 関節軟骨は, 全体的飞淡黄色 を呈し，骨折は略々中央部に認められ，完全に二分さ れていた，骨折面には海綿質が露出し，両骨片の骨湶 著は全然なかつた。

\section{組織所見}

骨折部の中心と思はれる部では, 滑膜と結合組織の 著明な增殖があり,リンパ管の増殖も著明であり，と れらの病巣に接して, 結合織性仮骨の新生が見られ る. 更に骨皮質に向うに従つて軟骨組織が形成され， 1 部は粘液様変化を起し, 骨梁は壊死飞陷り, 漸次正 常の骨梁に移行しているのか認为られる，骨皮質（遠 位端）には著変を認めない，以上の所見により明らか に骨折と判断するととが出来る.

\section{成 績}

術后 1 年 5 ケ月目では, 手関節の運動痛及び腫脹は 全くなくなり，レ線上右手舟状骨は完全な骨瘜合がみ られたが，左手舟状骨は術后 1 年 2 ケ月のレ線では, 仮関節を作り, 骨瘜合の像は認められなかつた。尚左 手関節の軽度疼痛と背屈運動障害が残つている.

症例 2 17才 男子 高校バレー選手, 中衛

既往歴 特記すべき事項なし.

家族歴 特記すべき事項なし.

現病歴

昭和 36 年 4 月, バレーボール練習中, 左手関節を捻 挫したが別に練習には差支えないのでそのまま練習を 続けていた，その后段々，左手関節を背届する時に疼 痛を覚える様になつた， 2,3 ケ月後には, 反対の右 手関節部に同様の運動痛が起り, 特に高い処のカバン を降す際等に，右手関節部に痛みを感ずる様になつた ので, 症状出現后 8 ケ月目に両手関節の運動痛を主訴 として, 当科外来を訪れた.

\section{現 症}

両手関節部背側には腫脹発赤熱感は認められない。 両手舟状骨部に圧痛はさほど著明ではないが, 両手関 節は最大屈曲運動で疼痛を訴え, 右手より左手に強く 運動痛が認められた．尚手指の知覚障害や運動障害は 認められない。

\section{レ線所見}

両舟状骨は前后像で, 症例 1 と同様, 略々中央部で 明膫な透明帯が見られる (写真 2$).$

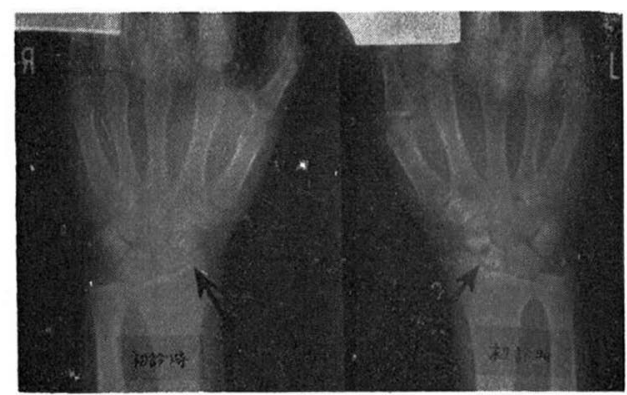

写真 2 症例 2 初䇏時

治 療

最初症状の強い右手舟状骨に観血的飞銀行骨による 骨移植術を行い, 約 2 ケ月后に同様反対側の舟状骨に 骨移植術を行つた.

\section{手術所見}

症例 1 の場合と同様に皮膚切開を行つた. 手舟状骨 は略々中央部で骨折を認め, 表面は結合織で蔽はれて おり, 湶合しているが見えたが, ピンセットで骨片 を押すと骨折部で互いによく動くのがみられた．そと で骨折部を充分に, 小さな鋭匙で掻爬し，そてに銀行 骨を充顚した.

\section{組織所見}

前症例と異なる事は，骨折部近くに大きな異物巨細 胞がみられたことである.

成績

術后 8 ケ月目では, 両手関節は, 運動痛, 運動制限 及び腫脹は全く認められない, レ線上, 両舟状骨は完 全ではないが大体瘾合している.

\section{症例 3 15才，高校生 後衛}

前述の 2 症例は, いづれも同じ高校のバレ一部員 で，ての高校は非常にきびしいトレーニングを行つて いるととがわかつた，乙の事から私達は，他の部員に あ, バレーによる何等かの障害があるのではないかと 思い, 同校バレー部員 15 名について検診を行つたが, その中に発見されたあのである. この症例は臨床的に は右手関節の運動制限と，舟状骨汇相当する部位に圧 痛とを証明した. 更にレ線所見で，舟状骨の略々中央 部に横走する骨硬化像がみられた。これは未だ骨折の 像とは言えないが, 臨床的に圧痛及び運動障害のある 


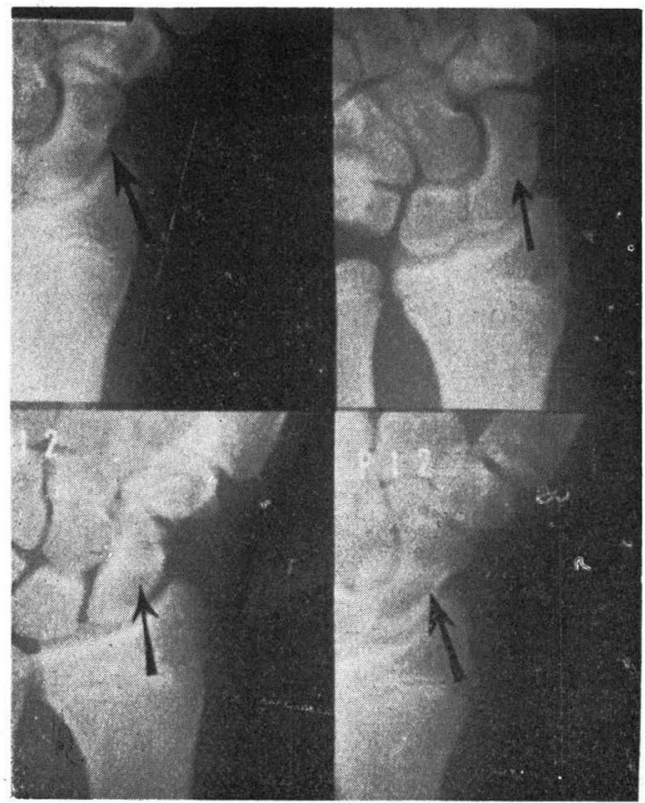

写真 3 症例 3 検彮時

ことから, 疲労骨折の準借状態と考えて良いと思わ れる. 尚今后むこの症例の経過を観察して行きたいと 思う (写真 3 ).

\section{考按}

以上私達が経験した症例は, いづれも高校バレ一部 員であり, この高校は昨年度は全国高校バレ一大会で 準優勝をなしとげた所謂名門校である.このバレーボ 一ルによる, 舟状骨々折の発生機転として私達は次の 様に考えている. 普通手舟状骨々折の発生機転として は，手関節を背届し，更に橈侧に屈曲した位置で手を ついた場合に起ることが多いとされているが，ボール をレシーブする際は, いづれの場合む手関節が背屈さ れ，且つ軽く橈屈される．特に強いスパイクボールを レシーブする時には, 外力が大きく䑠骨につ上い力 が作用するむのと思われる. 私達の症例の三例がスパ イクボールをうけることの多い, 守備位置であつたと とは,てのととをうらがきしている。文ボールを受け る場合，両肘関節をなかば屈曲してての関節を綏衝装 置とすれば，手関節には大きな衝撃力が作用しない が，低いスパイクボールを受ける場合は，とかく体勢 が崩れ，而も両肘関節を伸展したま〉受けることが多 く, 乙の場合, 肘関節のバネも利用出来ず, 手関節に 受ける衝撃は，相当大きいと考えなければならない. この高校は 1 年 350 日, 平均 1 日 3 時間以上の練習を
行つているとのととであるから, 手関節は, 非常に多 くの反覆する外力をうけ，遂にはその外力に抗しきれ ず, 疲労骨折を起すむのと考えられる.

この舟状骨骨折と鑑別しなければならないむのとし て, Os naviculare bipartitum carpi があるが，こ れは先天的に，手舟状骨が二分されたすので，しばし ば，骨折と間迲はれる. 然し，てれは比較的稀なすの で, Gruber によると，3007手に4 ケ発見されたにす ぎず, Waugh, Sullivanは, 1400 手に2 2 ケ (レント ゲンによる), Pfitznerによると 1450 手中 9 ケ（解剖 による）発見されたにすぎないのであるから，僅か 17名のバレー部員の中に, 4 ケの bipartitum が存在 しているとは到底考えられない，その上， bipartitum は, 臨床的には外傷の既症むなく, 限局性圧痛, 軽度 の腫脹も又運動痛及び, 運動障害も認められない事, 又解剖学的には Todd に上れば, 骨折の 場合は海綿 質が露出しているが， bipartitum は，その部分を蔽 う関節軟骨がみられ, その表面が smooth で, 光つ ていると述べている. 又私達の症例は, 既往症, 臨床 所見, 手術所見加らみてあ, 明らかに bipartitum と は区別するととが出来るむのと思う.

\section{結語}

以上私達は, 同一高校バレーボール選手に見られた 手舟状骨の疲労骨折と思われる 3 例について報告し， 併せてその発生機転について, 検討を加えてみた.

（終りに，御協力を睗つた直方高校吉永教諭をはじ めバレー部員に深謝する).

\section{文献}

1) Waugh, R. L. etc.: J. B. J. S., 32-A, 3, 682. 1950.

2) Burrows, H. J.: J. B. J. S., 38-B, 1, 83. 1956.

3) Devas, M. B.: J. B. J. S., 38-B, 1, 818. 1956.

4) Devas, M. B.: J. B. J. S., 40-B, 2, 227. 1958.

5) Devas, M. B.: J. B. J. S., 42-B, 3, 508. 1960.

6) Devas, M. B.: J. B. J. S., 43-B, 3,540. 1961.

7) Cotta, H.: Archiv für Orthopadische u. Unfall-Chirurgie. 52, 581-589. 1961.

8) Köhler, A. \& Zimmer, E. A.: Grenzen des Normalen und Anfänge des Pathologischen im Röntgenbilde des Skelettes. Georg Thieme Verlag. 1956.

9) 玉井: 外科の領域. 5, 889.

10）水町：日整会誌. 30,221 , 昭 31 .

11）松田：日外会誌. 58, 501, 昭 32 .

12）武山：整形外科. 12, 732, 昭 36. 